\title{
Calibrating an FDS simulation of goods vehicle fire growth in a tunnel using the Runehamar fire experiment
}

\author{
M. K. CHEONG \\ Land Transport Authority of Singapore, No.1 Hampshire Road, Singapore 219428 \\ M. J. SPEARPOINT AND C. M. FLEISCHMANN* \\ Department of Civil and Natural Resources Engineering, University of Canterbury, \\ Private Bag 4800, Christchurch, New Zealand
}

\begin{abstract}
As with any complex fuel assembly configuration, modelling a goods vehicle fire using FDS to estimate the heat release rate in a tunnel is a challenging task. The work presented in this paper involves the use of heat release rate curve taken from the Runehamar tunnel fire experiment $\mathrm{T} 1$ to 'calibrate' the heat release rate curve predicted using FDS 4.0.7. The paper develops a simplified representation of burning wood and plastic pallets and illustrates that an FDS simulation is able to reproduce a reasonable estimate of the fire growth characteristics in the tunnel. The paper considers the effects of the assumptions made to calibrate the simulations and then investigates how the fire growth might change if conditions were varied.
\end{abstract}

KEY WORDS: heat release rate, numerical simulation, tunnel fire reconstruction.

\section{INTRODUCTION}

The use of ventilation systems to control smoke movement is common in most road tunnel designs. The operation of the tunnel ventilation system is critical as its purpose during a fire emergency is to control the movement of smoke and heated gas away from the fire to provide a tenable environment along the egress path allowing for safe evacuation of motorists. The secondary purpose is to facilitate fire fighters access to the incident by providing a clear path to the fire site [1].

\footnotetext{
* Author to whom correspondence should be addressed. Email: charles.fleischmann@canterbury.ac.nz
} 
The risk of having a fire in a tunnel and designing an effective tunnel ventilation system through the provision of sufficient airflow to achieve tenable conditions in the egress path is dependent on multiple parameters including heat release rate (HRR), tunnel geometry, tunnel gradient, operation (whether bi-directional traffic is required) [1] and legislation (whether vehicles carrying dangerous goods are allowed to access the tunnel, e.g. petrol tankers). Among these parameters, the heat release rate is the primary parameter for tunnel ventilation design and it is the most difficult to identify as this value is dependent on the types of vehicles and any associated loads carried by the vehicles. In current practice, the heat release rate for various types of fires proposed by the PIARC 1999 technical committee reports [2], NFPA 502 [3] , BD78/99 [4] have generally been used for the design of tunnel ventilation systems. The heat release rates for the various types of vehicle fire range from $2.5 \mathrm{MW}$ to $5 \mathrm{MW}$ for passenger cars to $20 \mathrm{MW}$ to $30 \mathrm{MW}$ for heavy goods vehicles (HGV). However, recent fire experiments conducted in the Runehamar Tunnel showed that vehicles with burning goods may result in higher HRR (approx 66.4 to 201.9 MW peak) outputs [5]. These experiments seriously hinted that previous data regarding heavy goods vehicles might have been underestimated.

The purpose of this paper is to present an approach using a CFD computer program, Fire Dynamics Simulator (FDS) to establish the heat release rate in a tunnel considering factors such as tunnel geometry, ventilation condition and fuel load. Obtaining the fire growth of any burning fuel package using a computer model is a difficult exercise. The recent attempts to predict fire development prior to the Dalmarnock experiments [6] has showed some of the very considerable difficulties involved in doing this. Amongst other things, the work described in this paper involves a relatively complex 3-dimensional fuel package of varying material types which is also subject to a forced ventilation and reradiation effects. Therefore this work does not attempt to predict the fire growth a priori but uses published experimental data taken from one of the Runehamar tunnel fire experiment to 'calibrate' the heat release rate curve predicted using FDS 4.0.7. Similar to modelling work discussed in ref. 6, 'calibrate' in this context refers to a process to establish a relationship between the experimental value with the numerical analysis by considering the modelling approach used, the fuel arrangement, grid size and domain length. The objective of this simulation is to develop a simplified representation of wood and plastic pallets burning in a tunnel to illustrate that the simulation is able to reproduce a reasonable approximation of the fire growth characteristics and investigate the sensitivity of the baseline 'calibrated' model setup. When sufficient confidence level is achieved from the simulation, a similar approach can be used to establish the heat release rate for a design application. The work discussed in this paper is applicable to scenarios where a similar fuel arrangement to the Runehamar tunnel fire experiment is used for the simulation. Further calibration work would be necessary if other types of fuel materials or fuel arrangement setup were used for the numerical analysis. 


\section{THE RUNEHAMAR TUNNEL EXPERIMENT}

In 2003, a programme of large-scale fire experiments was conducted in the Runehamar tunnel in Norway [7]. This is an abandoned tunnel that has been closed down from traffic. It has previously been used for fire testing of various tunnel insulation materials. The Runehamar tunnel is dug into hard gneiss rock and is $1600 \mathrm{~m}$ in length, $9 \mathrm{~m}$ wide and $6 \mathrm{~m}$ high with a slope varying between 0.5 to $1 \%$ [8], the tunnel cross sectional area is shown in Figure 1. A total of four fire experiments were performed using a semi-trailer mock up with different commodities as the fuel source. These commodities included wood pallets, polyethylene plastic pallets, cardboard cartons containing polystyrene cups, polyurethane (PU) mattresses and furniture. The commodities used as fuel in the four experiments are shown and tabulated in Figure 2 and Table 1 respectively.

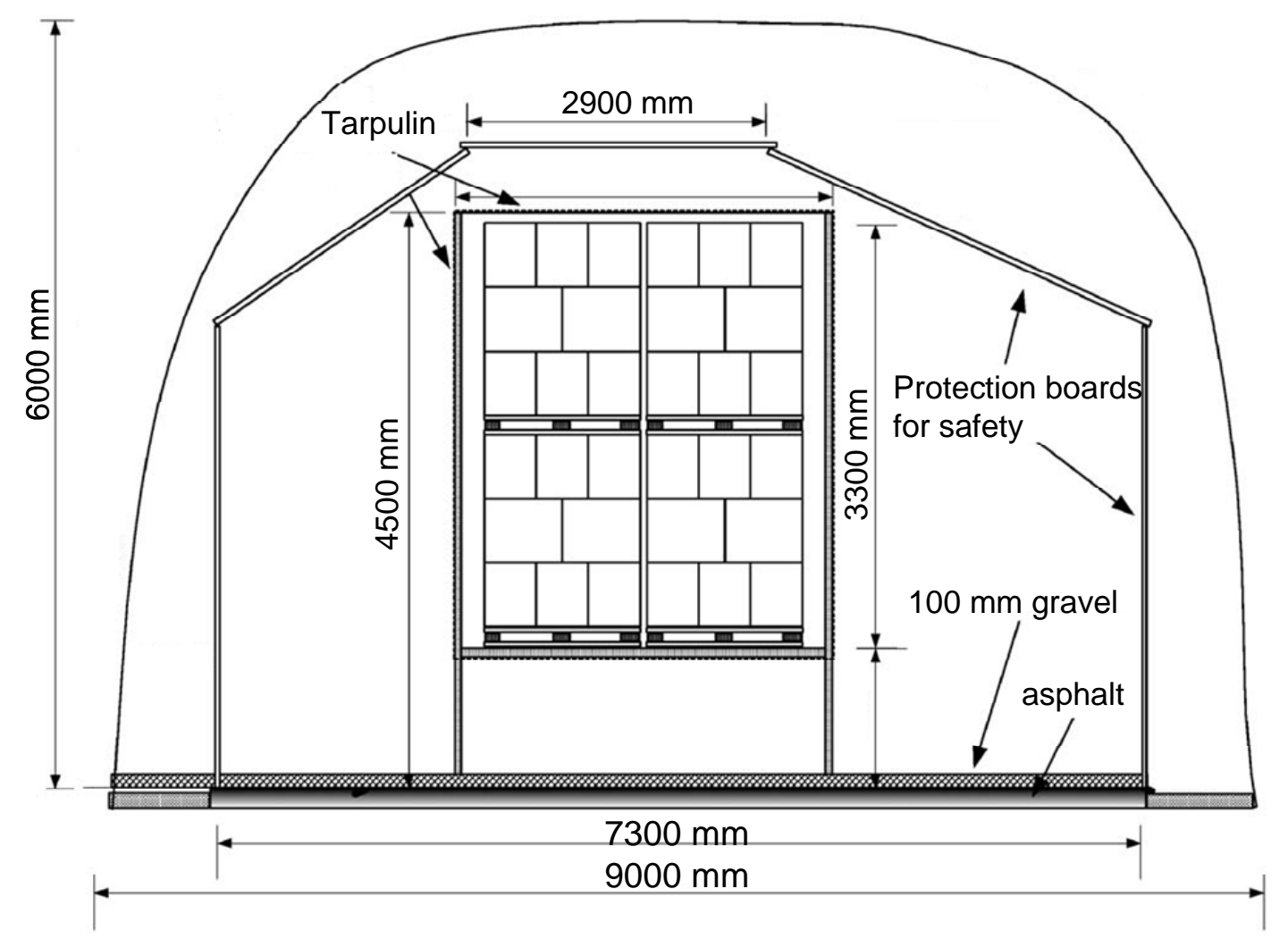

Figure 1: Cross section of Runehamar tunnel [9] 


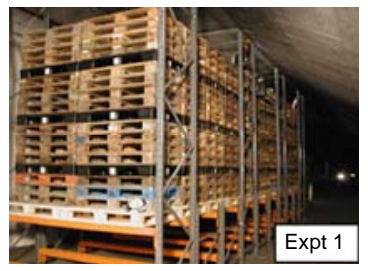

Wood and PE pallets

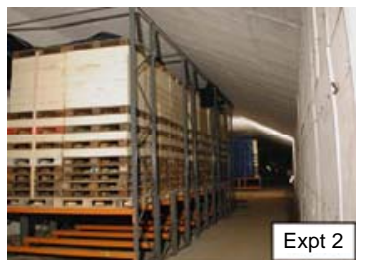

Wood pallets and mattresses

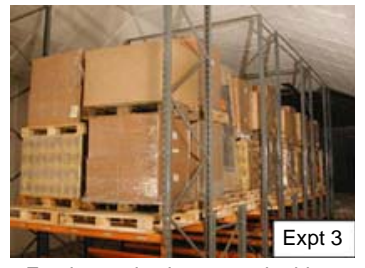

Furniture, plastic toys and rubber tyres

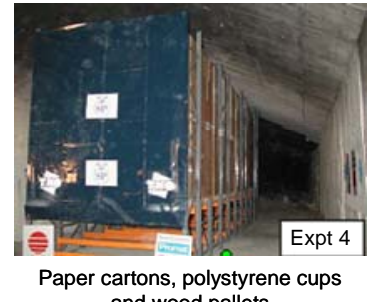

and wood pallets

Figure 2: Photographs of fuel load used in fire experiments [9]

The experiments were conducted by the SP Swedish National Testing and Research Institute. Measurements included gas temperature, visibility, thermal radiation and gas species. A sketch of the measuring station setup and overview of the measurement position in the tunnel is shown in Figure 3. The heat release rate was calculated using the oxygen consumption calorimetry technique for the data at the downstream station [8]. A mobile fan positioned at the tunnel entrance generated an air velocity of $3 \mathrm{~m} / \mathrm{s}$ driving the fire gases in one direction enabling the heat release rate to be measured at the opposite end of the tunnel. The maximum heat release rate varying between $66.4 \mathrm{MW}$ to 201.9 MW was recorded in these tests [8]; the HRR curves for the four experiments are shown in Figure 4. 


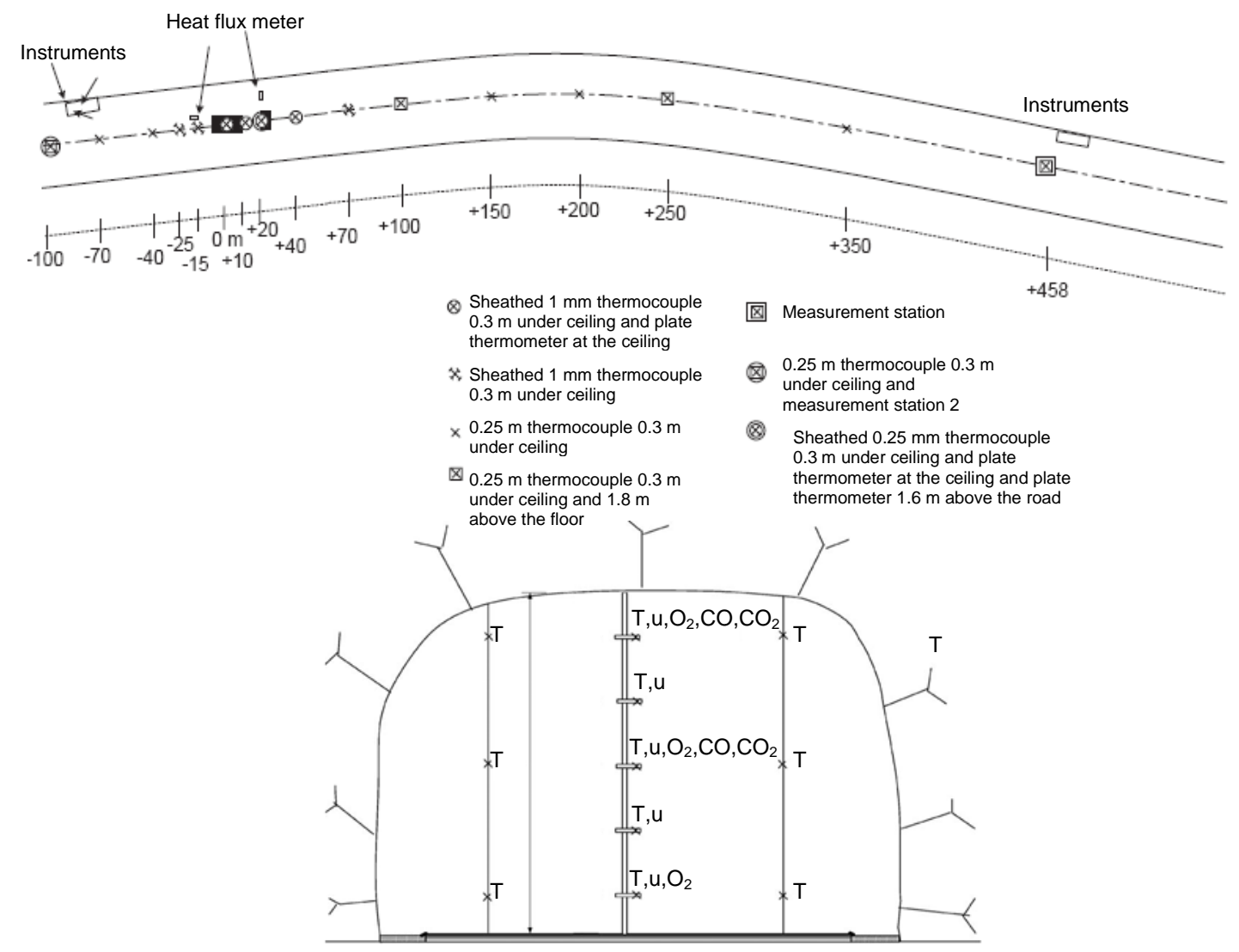

Note: $T$ = gas temperature, $u=$ gas velocity, $\mathrm{CO}_{2}=$ carbon dioxide, $\mathrm{CO}=$ carbon monoxide, $\mathrm{O}_{2}=$ oxygen, $\mathrm{OD}=$ visibility.

Figure 3: Measurement station used in the Runehamar Tunnel fire experiments [5, 8].

\begin{tabular}{|c|c|c|c|}
\hline Description of fuel load & $\begin{array}{l}\text { Total } \\
\text { weight } \\
(\mathrm{kg})\end{array}$ & $\begin{array}{c}\text { Theoretical } \\
\text { calorific value } \\
(\mathrm{GJ})\end{array}$ & $\begin{array}{l}\text { Measured } \\
\text { peak HRR } \\
(\mathrm{MW}) \\
\end{array}$ \\
\hline $\begin{array}{l}360 \text { wood pallets measuring } 1.2 \mathrm{~m} \text { x } 0.8 \mathrm{~m} \text { x } 0.15 \mathrm{~m} \\
20 \text { wood pallets measuring } 1.2 \mathrm{~m} \mathrm{x} 1 \mathrm{~m} \times 0.15 \mathrm{~m} \\
74 \text { PE plastic pallets measuring } 1.2 \mathrm{~m} \text { x } 0.8 \mathrm{~m} \text { × } 0.15 \mathrm{~m}\end{array}$ & 11010 & 247 & 201.9 \\
\hline $\begin{array}{l}\text { Wood pallets measuring } 1.2 \mathrm{~m} \text { x } 0.8 \mathrm{~m} \times 0.15 \mathrm{~m} \\
\text { PU mattresses }\end{array}$ & 6930 & 135 & 156.6 \\
\hline $\begin{array}{l}\text { Furniture and fixtures } \\
\text { Ten large rubber tyres } \\
\text { Polyester tarpaulin } \\
\end{array}$ & 8550 & 179 & 118.6 \\
\hline $\begin{array}{l}\text { Corrugated paper cartons } \\
\text { Polystyrene (PS) cups, Wood pallets } \\
\text { Polyester tarpaulin }\end{array}$ & 2850 & 62 & 66.4 \\
\hline
\end{tabular}

Table 1: Fuel load used for the Runehamar Tunnel fire experiments [5] 


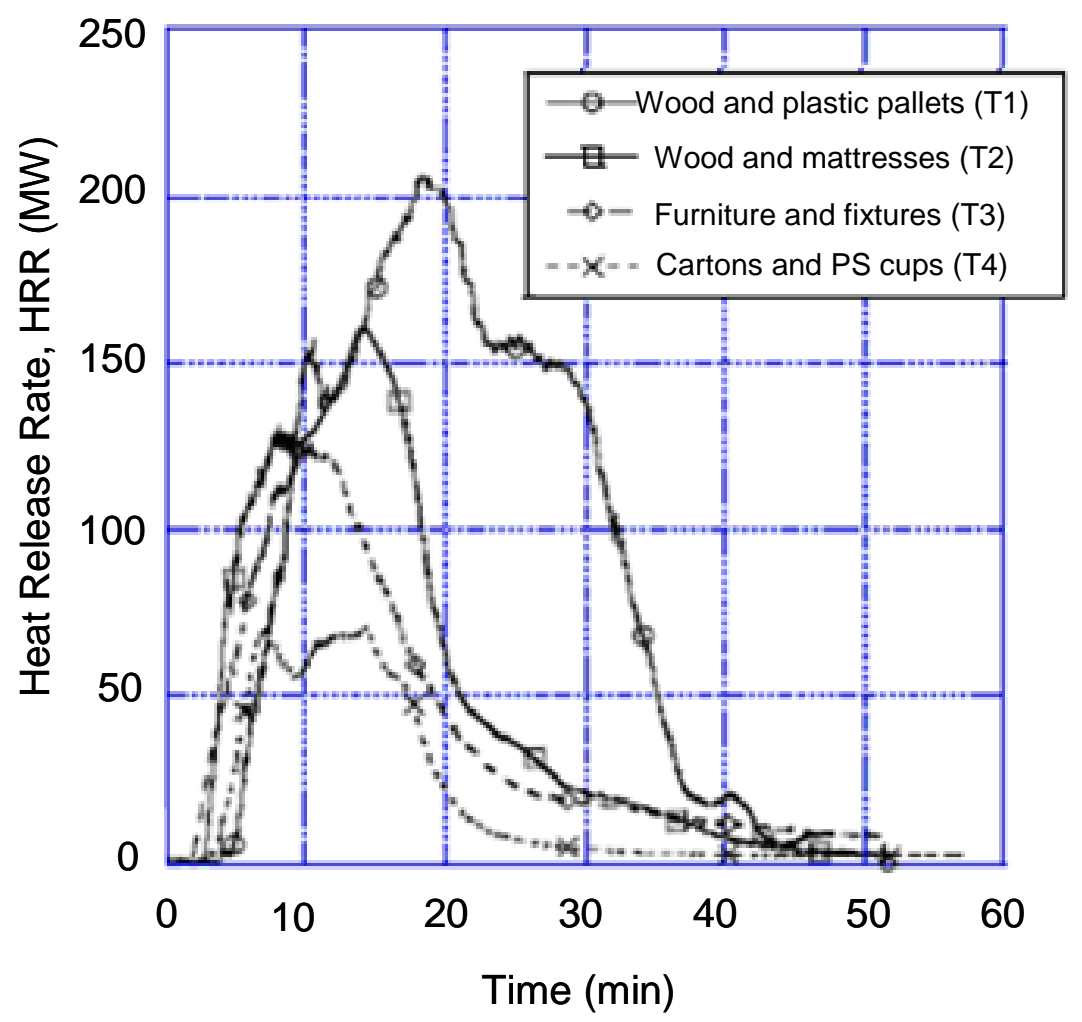

Figure 4: HRR recorded for the four Runehamar Tunnel fire experiments [5]

\section{MODELLING OF FIRE EXPERIMENT T1}

\section{FDS model and stability criteria}

For this work, FDS 4.0.7 was used for the calibration of the Runehamar tunnel fire experiment T1. The equations in FDS code include the conservation of mass, species, momentum, energy and equation of state where this is a set of partial differential equations to compute the density, three components of velocity, mass fraction, temperature and pressure [10]. In the Large Eddy Simulation turbulence model where the grid is not fine enough to resolve the diffusion of fuel and oxygen, a mixture fractionbased combustion model is used. Combustion is calculated from the mixing rate of fuel and oxidant where the chemical reaction between fuel and oxygen are taken to follow a single one-step stoichiometric reaction. The assumption that fuel and oxidizer cannot coexist leads to the state relations between the oxygen mass fraction and mixture fraction [10]. In FDS, the total heat release rate is established using

$$
\dot{Q}=\Delta H_{O 2} \int_{F}-\dot{m}_{O 2}^{\prime \prime \prime} d A=\Delta H_{o 2} \int_{F} \frac{d Y_{o}}{d Z} \rho D \nabla Z d S
$$

As the conservation equations in FDS are coupled together, a change in the velocity will affect the density, mass fraction of the species or mixture fraction and so indirectly affect the heat release rate estimate. The velocity components in each grid cell will be a 
combination of any imposed external velocity, the effects of any combustion in neighbouring cells and the influence of obstructions.

According to McGrattan [10], FDS model solves numerically a form of the NavierStokes equation and discretises the domain using an explicit scheme. The domain is made up of a rectangular box that is divided into rectangular grid cells. To ensure that the results computed are numerically correct, the time step is constrained by the CourantFriedrichs-Lewy (CFL) condition where:

$$
\delta t \max =\left(\frac{u}{\delta x}, \frac{v}{\delta y}, \frac{w}{\delta z}\right) \leq 1
$$

The velocities $u, v$ and $w$ are tested at each time step to ensure that the CFL condition is satisfied. If the above is greater than 1 , the time step is set to 0.8 of its allowed maximum value and these velocities are recalculated and tested again. CFL is used to assess the solution to the equations and it cannot be updated with a time-step larger than 1 resulting in a parcel of fluid crossing a grid cell [10]. This process helps to enhance the stability of the simulation but can result in long computational times where a fine grid is used and/or a large domain is specified.

To achieve a more realistic simulation, the "Burn away" function in FDS was used to make an object disappear from the computational domain once its fuel had been exhausted and further details can be found in the FDS user guide [11]. However it is recognised that there are some important phenomena such as any change in the shape of fuel package after collapse of the fuel during the burning process cannot be captured by FDS. FDS is also limited in its ability to model the effects of solid materials like wood related to glowing effects of the material.

\section{Tunnel conditions}

To capture the effect of re-radiation, the geometry of the tunnel and the wall lining material were included in the simulation. The thermal conductivity, density and specific heat used for the fire board in the simulation were $0.48 \mathrm{~W} / \mathrm{m} / \mathrm{K}, 1440 \mathrm{~kg} / \mathrm{m}^{3}$ and $0.84 \mathrm{~kJ} / \mathrm{kg} / \mathrm{K}$ respectively [12].

In the experiments, one of the considerations was to protect the tunnel with high temperature resistant fire board insulation as high thermal outputs were expected [13]. The provision of the fire board would also mean that the tunnel section was smaller and the effect of re-radiation was higher. Therefore, geometry details relating to the provision of the fire board was included in the simulation. A baseline domain size of $9.3 \mathrm{~m}$ (width) by $6.3 \mathrm{~m}$ (height) by $93 \mathrm{~m}$ (length) was selected for the simulations and Figure 5 provides the internal tunnel geometry and fire board dimensions used. 

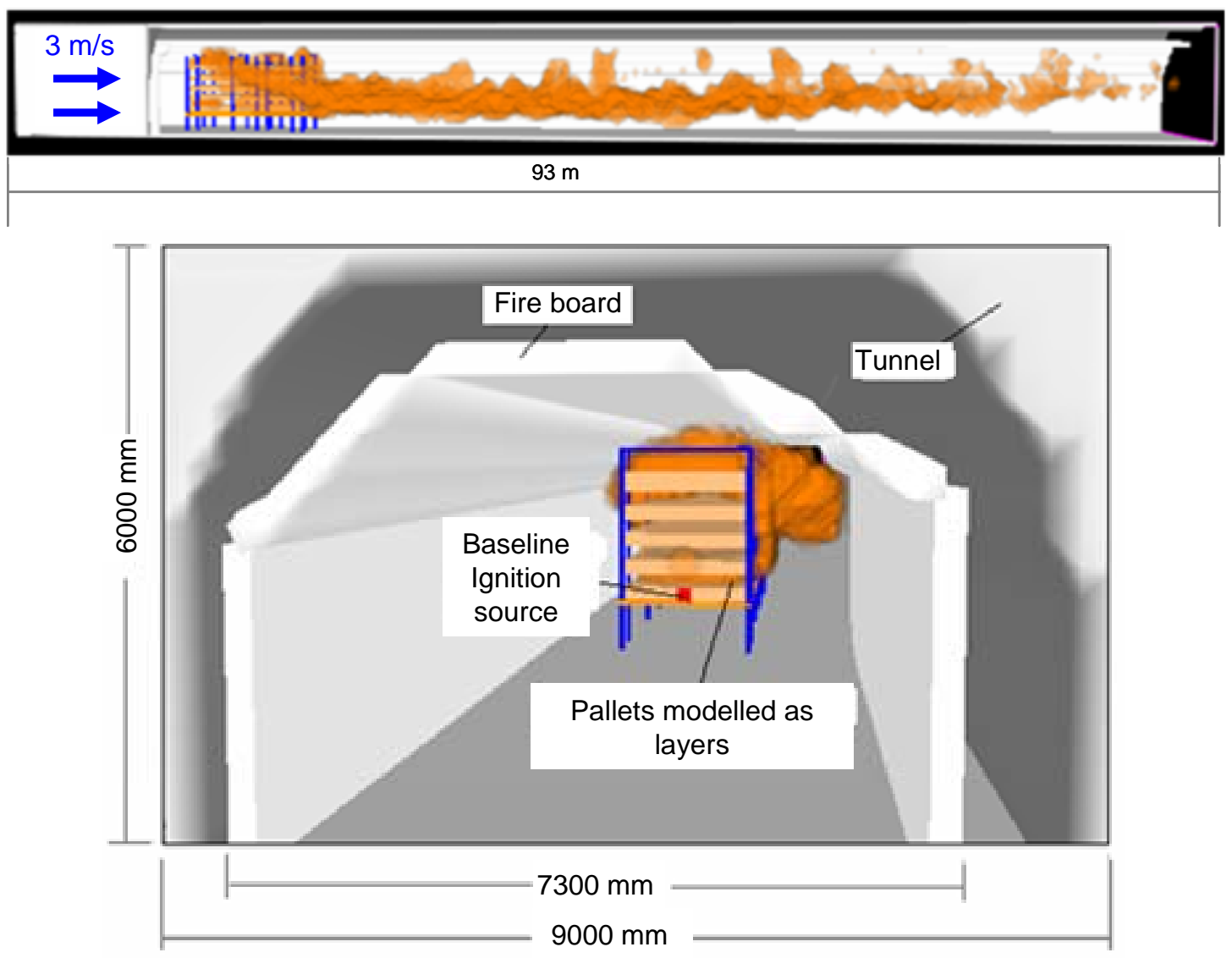

Figure 5: Cross section of the Runehamar tunnel showing the geometry set up for the simulations.

As the thermal properties of hard gneiss rock are not available, the thermal properties of concrete were used instead as a baseline. The concrete thermal conductivity, density and specific heat used for the simulation were $1.0 \mathrm{~W} / \mathrm{m} / \mathrm{K}, 2100 \mathrm{~kg} / \mathrm{m}^{3}$ and $0.88 \mathrm{~kJ} / \mathrm{kg} / \mathrm{K}$ respectively [12].

To create a longitudinal airflow in the tunnel, an external forced ventilation boundary condition was provided at the upstream boundary of the tunnel section with the downstream boundary being open to the atmosphere. A baseline upstream uniform velocity of $3 \mathrm{~m} / \mathrm{s}$ was appropriate to match the experiment.

\section{Fuel geometry}

According to Ingason and Lonnermark [5], the commodities used for each fire experiment represent a specific category of material found in the cargo of semi-trailers. From the experimental results, fire experiment $\mathrm{T} 1 \mathrm{had}$ the greatest calorific value and the highest peak heat release rate. Selecting experiment T1 for the calibration of the FDS modelling approach and subsequently using it for design fire simulation work provides a certain degree of conservativeness for tunnel fire hazard analysis. 
Three types of pallets were used in the T1 experiment; $1.2 \mathrm{~m} \mathrm{x} 0.8 \mathrm{~m} \times 0.15 \mathrm{~m}$ wood pallets, $1.2 \mathrm{~m} \times 1 \mathrm{~m} \times 0.15 \mathrm{~m}$ wood pallets and $1.2 \mathrm{~m} \times 0.8 \mathrm{~m} \times 0.15 \mathrm{~m}$ polyethylene plastic pallets. According to White [14], pallets of this range of dimension are known as EURO pallets which are one of the internationally recognised standard pallets commonly used in Europe. The authors have made certain assumptions concerning the modelling of the pallets for the Runehamar tunnel fire experiment using FDS. These assumptions include:

1) Dimensions for the wood and plastic pallets were based on EURO pallets.

2) The fuel package was modelled in layers consisting of $80 \%$ wood and $20 \%$ polyethylene (PE) plastic.

3) These wood or plastic pallets were modelled as a composite material by summing their mass and redistributing it into layers of rectangular elements equivalent to the size of the trailer. The advantage of this approach is that large scale fires with a complex fuel configuration can be simulated.

4) The thermal properties for wood and polyethylene were taken from cone calorimeter tests. The cone test data for wood taken from Thureson [15] and polyethylene taken from Babrauskas and Grayson [16]. Figures 6 and 7 show the heat release rate per unit area (HRRPUA) cone test data at specified exposure heat fluxes for wood and polyethylene that were used in the FDS simulations. The wood and polyethylene thermal conductivity, density, ignition temperature and specific heat are tabulated in Table 2.

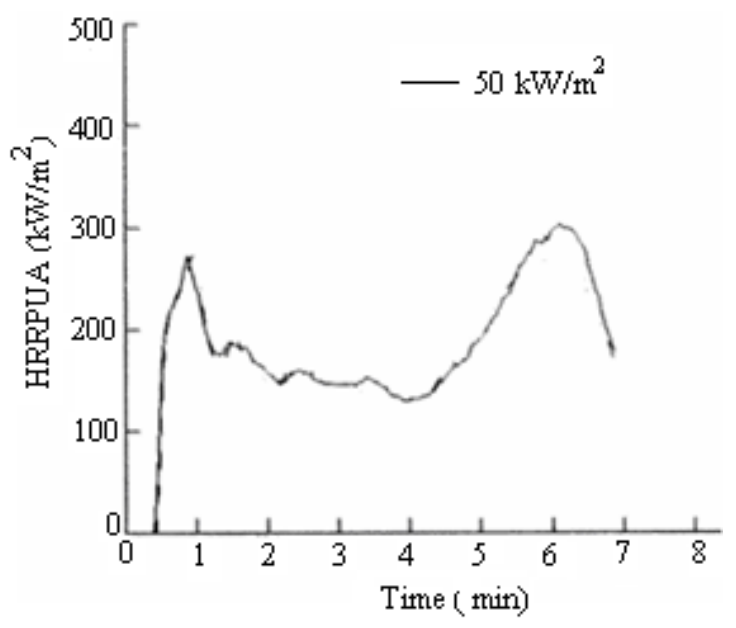

Figure 6: HRRPUA for plywood [15] exposed at $50 \mathrm{~kW} / \mathrm{m}^{2}$.

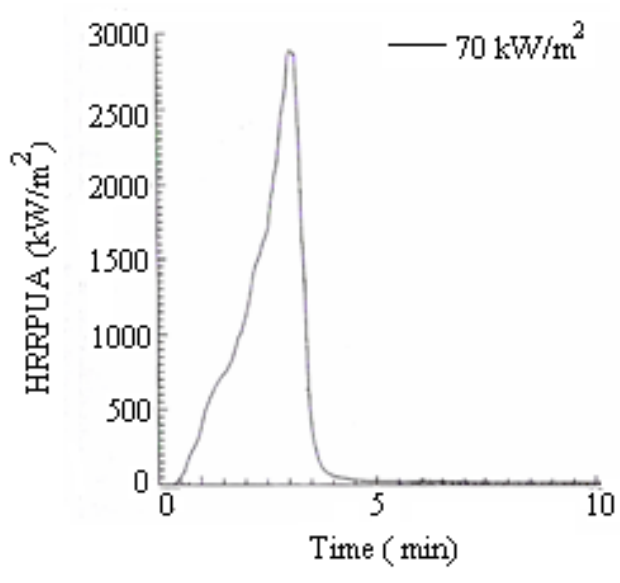

Figure 7: HRRPUA for plastic [16] exposed at $70 \mathrm{~kW} / \mathrm{m}^{2}$. 


\begin{tabular}{|l|c|c|c|c|}
\hline Material & $\begin{array}{c}\text { Thermal } \\
\text { conductivity } \\
(\mathrm{W} / \mathrm{m} . \mathrm{K})\end{array}$ & $\begin{array}{c}\text { Density } \\
\left(\mathrm{kg} / \mathrm{m}^{3}\right)\end{array}$ & $\begin{array}{c}\text { Ignition } \\
\text { temperature } \\
\left({ }^{\circ} \mathrm{C}\right)\end{array}$ & $\begin{array}{c}\text { Specific } \\
\text { heat } \\
(\mathrm{kJ} / \mathrm{kg} . \mathrm{K})\end{array}$ \\
\hline Plywood $^{\mathrm{a}}$ & 0.12 & 600 & 373 & 2.58 \\
\hline Polyethylene $^{\mathrm{b}}$ & 0.64 & 956 & 323 & 3.00 \\
\hline
\end{tabular}

Note: a) Cone test data taken from Thureson [15]

b) Cone test data taken from Babrauskas and Grayson [16] and Babrauskas [17]

Table 2: Cone test data for wood and polyethylene

In the T1 fire experiment, a total of 454 pallets were used and fuel load was set up in the proportion by mass ratio of $80 \%$ wood and $20 \%$ plastic. The arrangement of the wood and plastic pallets burned in the experiment is shown in Figure 8.

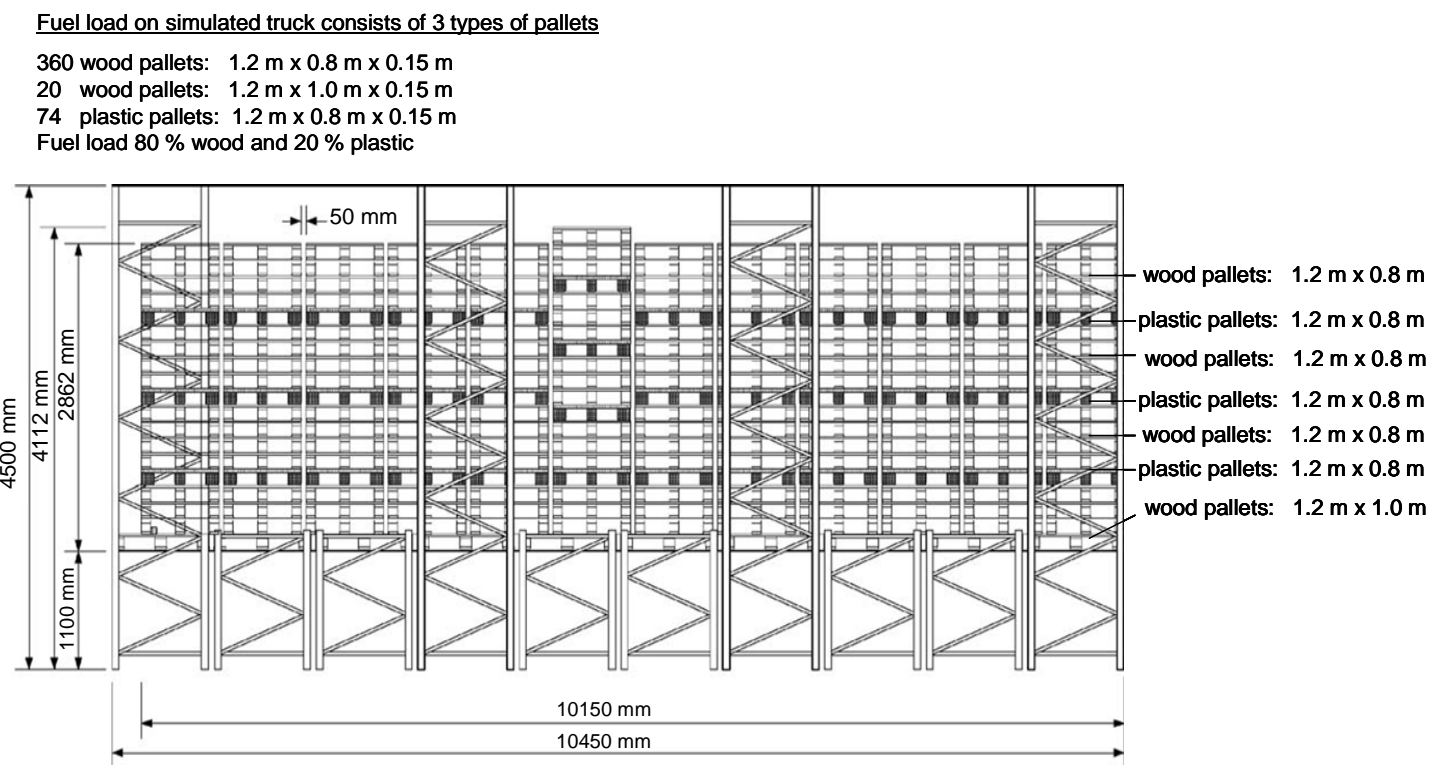

Figure 8: Pallet fuel load burned in the T1 Runehamar experiment

In setting up calculation in the FDS simulation, it is necessary to specify geometry in the space and apply boundary conditions to the objects modelled. An object in the FDS simulation is defined as an obstruction (OBST) which can heat up, burn and conduct heat depending on the type of boundary condition specified. Details of various types of boundary conditions are discussed in the FDS user guide [11]. The time dependent boundary condition was used in this work to estimate the heat release rate for the Runehamar tunnel fire experiment. Burning histories based on heat release rate per unit area taken from cone calorimeter tests were used. When the burning of an obstruction commences, the heat release rate per unit area was ramped up where ' $T$ ' is the time in seconds and ' $F$ ' indicates the fraction of the heat release rate per unit area (Figure 9) to match the data obtained in the appropriate cone calorimeter test. 


\begin{tabular}{|c|c|}
\hline FDS input parameters for wood material & Remarks \\
\hline = 'WOOD PALLETS $1.2 \mathrm{X} 1$ ' & \\
\hline = 'PLYWOOD ORDINARY' & \\
\hline$=0.12$ & Refer to Table 2 \\
\hline DENSITY & Refer to Table 2 \\
\hline$=2.58$ & Refer to Table 2 \\
\hline$=0.0125$ & With the pallet mass or volume identify, the thickness can be established \\
\hline BURN_AWAY $=$.TRUE. & To make object disappear once fuel is exhausted \\
\hline TMPIGN $=373$ & Refer to Table 2 \\
\hline$=$ 'INSULATED' & \\
\hline HRRPUA & {$[\mathrm{SBF} \times$ cone test peak HRRPUA $=310 \times 1.36=421.6]$} \\
\hline RAMP_Q & Refer to Figure 6 \\
\hline \&RAMP ID='GAP1',T=0.0,F=0 & Refer to Figure 6 \\
\hline \&RAMP ID='GAP1',T=68.0,F=0.85 / & Refer to Figure 6 \\
\hline \&RAMP ID='GAP1',T= 120.0,F=0.53 / & Refer to Figure 6 \\
\hline \&RAMP ID='GAP1', $\mathrm{T}=180, \mathrm{~F}=0.48$ & Refer to Figure 6 \\
\hline \&RAMP ID='GAP1',T= 240,F=0.4 / & Refer to Figure 6 \\
\hline \&RAMP ID='GAP1', $\mathrm{T}=300, \mathrm{~F}=0.64$ & Refer to Figure 6 \\
\hline \&RAMP ID='GAP1',T= 383,F=1 , / & Refer to Figure 6 \\
\hline \&RAMP ID='GAP1',T= 420,F=0.54 , & Refer to Figure 6 \\
\hline
\end{tabular}

Figure 9: FDS input file extract showing an example of the material property specification

One of the constraints of this modelling approach is the limitation in the available computational capability. Considering the complexity of the pallet construction it was not feasible to model an exact physical representation of each pallet as a substantial number of grid cells, each of the order of $0.01 \mathrm{~m}$ or smaller, would be required to capture the geometrical detail resulting in huge computational run times. Therefore to overcome this limitation, the geometry of the pallets was simplified into layers.

From an examination of the pallet arrangement in the experiment it can be seen that for every 4 layers of wood pallets there is a layer of plastic pallets. This stacking arrangement is repeated for three times followed by a single layer of wood pallets contributing a total of 360 wood pallets $(1.2 \mathrm{~m} \mathrm{x} 0.8 \mathrm{~m}), 20$ wood pallets $(1.2 \mathrm{~m} \mathrm{x} 1 \mathrm{~m})$ and 74 polyethylene pallets $(1.2 \mathrm{~m} \mathrm{x} 0.8 \mathrm{~m})$. The simulation model was constructed using five layers each having dimensions with a multiple of $0.15 \mathrm{~m}$ to maintain volumes similar to the actual fire experiment. Considering the plastic pallets are sandwiched between every four layers of wood pallets, the fuel package arrangement in the simulation was specified to mimic the fuel arrangement in a similar way to the experiment.

For this type of modelling approach, it is important to ensure the fuel package surface area in the simulation is equivalent to the fuel package area used in the fire experiments. However, it is often not possible to equate a simulated fuel package surface area with the actual fuel area if a simplified fuel geometry is constructed in the simulation. A surface burning factor (SBF) is introduced here to overcome this shortfall. The surface burning factor is established by dividing the surface area of the gross bounding volume of a pallet fuel package by the fuel package area modelled in the simulation. This SBF value is multiplied by the heat release rate per unit area from the cone test data and subsequently used in the simulation. 
An illustration to determine the surface burning factor for layer 5 (20 wood pallets) is shown as follows:

- The total surface area for layer 5 in the FDS simulation is $(9.9 \mathrm{~m} \times 2.7 \mathrm{~m} \times 2)+$ $(9.9 \mathrm{~m} \times 0.3 \mathrm{~m} \times 2)+(2.7 \mathrm{~m} \times 0.3 \mathrm{~m} \times 2)=61.02 \mathrm{~m}^{2}$;

- The total surface area of exposed faces per wood pallet ( $1.2 \mathrm{~m}$ by $0.8 \mathrm{~m}$ by $0.15 \mathrm{~m})$ $=4.14 \mathrm{~m}^{2}$;

- The total surface area of exposed faces for 20 pallets is $20 \times 4.14=82.8 \mathrm{~m}^{2}$;

- Therefore the surface burning rate factor used for the FDS simulation is $\frac{82.8}{61.02}=1.36$.

The baseline arrangement of the fuel load layout modelled in the simulation is shown in Table 3 and Figure 10. The 'centre' properties for each layer refers to the vertical faces of the layer as defined by the FDS input file.

\begin{tabular}{|c|c|c|c|c|}
\hline \multirow[t]{2}{*}{ Layer } & \multirow[t]{2}{*}{ Pallet dimensions } & Top & Centre & Bottom \\
\hline & & SBF/Material/Thickness & SBF/Material/Thickness & SBF/Material/Thickness \\
\hline 1 & $\begin{array}{c}1.2 \mathrm{~m} \mathrm{x} 0.8 \mathrm{~m} \mathrm{x} \\
0.15 \mathrm{~m}\end{array}$ & 10.22 / wood / $0.107 \mathrm{~m}$ & 10.22 / wood / $0.107 \mathrm{~m}$ & 10.22 / wood / 0.107 m \\
\hline 2 & $\begin{array}{c}1.2 \mathrm{~m} \times 0.8 \mathrm{~m} \mathrm{x} \\
0.15 \mathrm{~m}\end{array}$ & 5 / plastic / $0.03 \mathrm{~m}$ & 5 / plastic / $0.03 \mathrm{~m}$ & $7.26 / \operatorname{wood} / 0.076 \mathrm{~m}$ \\
\hline 3 & $\begin{array}{c}1.2 \mathrm{~m} \mathrm{x} 0.8 \mathrm{~m} \mathrm{x} \\
0.15 \mathrm{~m}\end{array}$ & 7.26 / wood / $0.076 \mathrm{~m}$ & $7.26 /$ wood / $0.076 \mathrm{~m}$ & 7.26 / wood / 0.076 m \\
\hline 4 & $\begin{array}{c}1.2 \mathrm{~m} \mathrm{x} 0.8 \mathrm{~m} \mathrm{x} \\
0.15 \mathrm{~m}\end{array}$ & 5 / plastic / $0.03 \mathrm{~m}$ & $7.26 /$ wood / $0.076 \mathrm{~m}$ & 7.26 / wood / 0.076 m \\
\hline 5 & $\begin{array}{c}1.2 \mathrm{~m} \mathrm{x} 1.0 \mathrm{~m} \mathrm{x} \\
0.15 \mathrm{~m}\end{array}$ & 1.36 / wood / $0.0125 \mathrm{~m}$ & 1.36 / wood / $0.0125 \mathrm{~m}$ & 1.36 / wood / $0.0125 \mathrm{~m}$ \\
\hline
\end{tabular}

Table 3: Re-distribution of plastic and wood pallets for baseline FDS simulation

Based on the fuel load arrangement shown in Table 3, the SBF for layer 1 to 5 varies from 1.36 to 10.24 . As the fuel quanity of each layer is adjusted by the SBF, layers with more pallets will have a higher SBF. This approach indirectly account for the total amount of energy consume in each layer. To minic the buring behaviour for experiment T1, plastic material is distributed among layers to establish the HRR curve that resembles the HRR curve from fire experiment T1. 


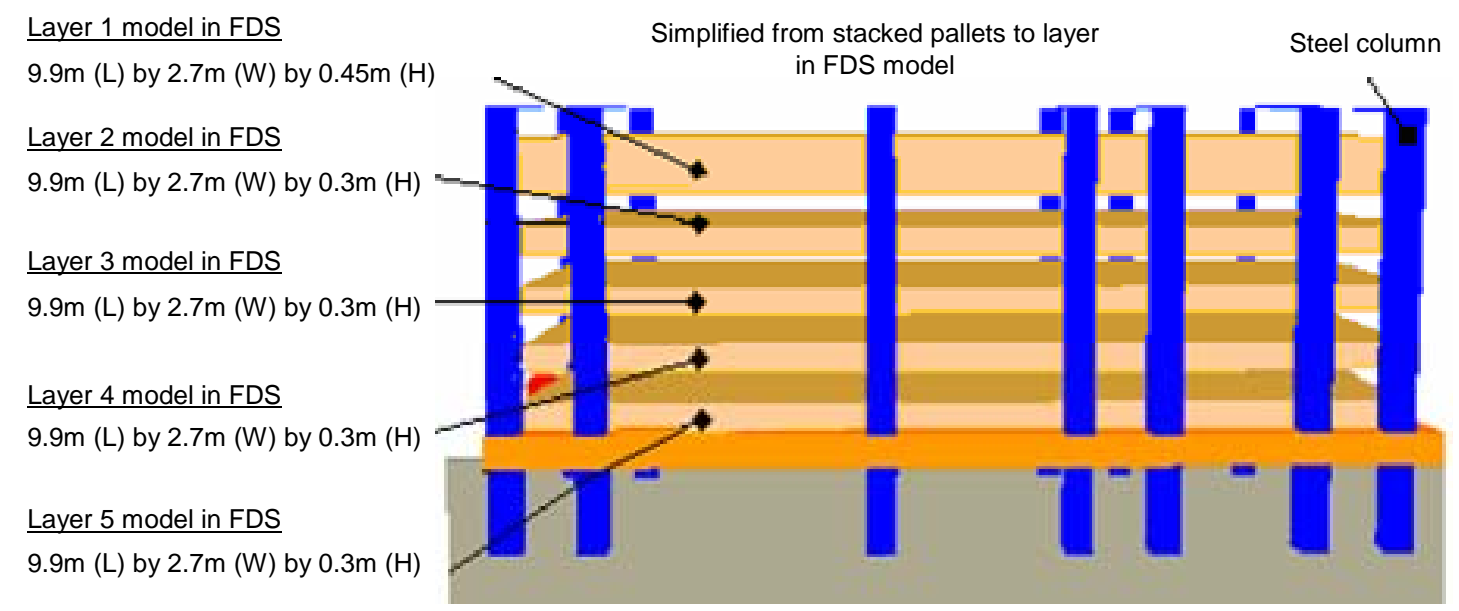

Figure 10: Representation of the fuel load pallets model for the Runehamar experiment

\section{SIMULATION RESULTS AND COMPARISONS}

Baseline simulations run for the Runehamar tunnel experiment T1 were based on conditions described earlier. Observations from the EUREKA [18] fire experiments and studies by Carvel et al. [19] have shown that ventilation condition, tunnel geometry, fuel configuration and even the location of ignition can affect the burning characteristics of a fire. The effect on the simulated fire growth of these parameters and the FDS representation of the Runehamar tunnel experiment T1 were investigated as part of the computational analysis.

The thermal properties of granite were used to examine if varying the tunnel material properties affected the simulation results. Granite thermal conductivity, density and specific heat of $2.85 \mathrm{~W} / \mathrm{m} . \mathrm{K}, 2640 \mathrm{~kg} / \mathrm{m}^{3}, 0.82 \mathrm{~kJ} / \mathrm{kg} . \mathrm{K}$ [20] respectively were used to replace the concrete properties selected for the baseline. Results from simulations using these two types of material did not vary by more than $2.3 \%$ and therefore material data for concrete was considered reasonable for the simulations.

The experimental results and the simulated results using FDS are presented in Figure 11a to 11e for comparison. The effect of grid size, domain length and fuel load configuration were investigated to select what were appropriate 'calibration' values. Although the airflow in the fire experiment was provided at $3 \mathrm{~m} / \mathrm{s}$, different air velocities were simulated to examine the impact of varying the airflow in the tunnel and its effect on the heat release rate curve. The location of the ignition source was also changed to observe the impact on the heat release rate curve. Table 4 shows a summary of the simulations conducted around the Runehamar tunnel fire experiment T1. 


\begin{tabular}{|c|c|c|c|c|c|}
\hline $\begin{array}{c}\text { Simulation } \\
\text { no. }\end{array}$ & $\begin{array}{l}\text { Ignition } \\
\text { location }\end{array}$ & $\begin{array}{c}\text { Grid size } \\
(\mathrm{mm}) \\
\end{array}$ & $\begin{array}{c}\text { Domain } \\
\text { length } \\
\text { (m) }\end{array}$ & $\begin{array}{c}\text { Tunnel } \\
\text { air flow } \\
(\mathrm{m} / \mathrm{s})\end{array}$ & Fuel arrangement \\
\hline 1 & Upstream & 150 & 93 & 3 & Fuel arrangement $1^{\mathrm{a}}$ \\
\hline 2 & Upstream & 300 & 36 & 3 & Fuel arrangement $1^{\mathrm{a}}$ \\
\hline 3 & Upstream & 300 & 87 & 3 & Fuel arrangement $1^{\mathrm{a}}$ \\
\hline 4 & Upstream & 300 & 93 & 3 & Fuel arrangement $1^{\mathrm{a}}$ \\
\hline 5 & Upstream & 300 & 102 & 3 & Fuel arrangement $1^{\mathrm{a}}$ \\
\hline 6 & Upstream & 300 & 93 & 3 & Fuel arrangement $2^{b}$ \\
\hline 7 & Upstream & 300 & 93 & 3 & Fuel arrangement $3^{c}$ \\
\hline 8 & Upstream & 300 & 93 & 1 & Fuel arrangement $1^{\mathrm{a}}$ \\
\hline 9 & Upstream & 300 & 93 & 1.5 & Fuel arrangement $1^{\mathrm{a}}$ \\
\hline 10 & Downstream & 300 & 93 & 3 & Fuel arrangement $1^{\mathrm{a}}$ \\
\hline
\end{tabular}

Note: a) Fuel arrangement 1: Refer to Table 3

b) Fuel arrangement 2: Plastic pallets positioned in layer 3

c) Fuel arrangement 3: Plastic pallets positioned in layers $2 \& 4$

Table 4: Summary of the FDS simulations performed around the Runehamar tunnel fire experiment

Figure 11a shows the simulation results performed on the $300 \mathrm{~mm}$ and $150 \mathrm{~mm}$ grid sizes. As described earlier, the pallets were modelled as $300 \mathrm{~mm}$ thick layers therefore using a grid size larger than $300 \mathrm{~mm}$ was not sufficient to capture the burning behaviour of the objects. Simulations using the $150 \mathrm{~mm}$ grid required almost 40 days to complete and limitations on computational power and available run times meant that finer grids could not be investigated. Results from the two grid size simulations show a considerable difference which cannot be easily explained particularly as they show that the $300 \mathrm{~mm}$ grid gave a more favourable result than the $150 \mathrm{~mm}$ grid. It would be typical to expect that the numerical solution will approach the 'exact' solution as finer grids are used but in this case there is no exact HRR for a burning goods vehicle. If the fire experiment were to be repeated under the same conditions it is inevitable that the HRR curve would be different. According to Beard [21], the peak HRR recorded in the Runehamar fire experiment has been estimated to be around $59^{\text {th }}$ percentile of possible results. Ideally replications of the fire experiments should be undertaken which would yield a distribution HRR data for comparison. Unfortunately such data are not available because of the cost and complexity of doing this. Clearly what is important is that the grid size has a significant influence on the simulation results and it is only through a calibration process that an appropriate grid can be determined. For this calibration exercise a $300 \mathrm{~mm}$ grid is found to give a reasonable match with the experiment where the 
simulated peak heat release rate of 190 MW compares to the experimental result of 201.9 MW.

Domain sensitivities were performed to ensure that the flame extension was captured in the simulation. Tunnel lengths of $36 \mathrm{~m}, 87 \mathrm{~m}, 93 \mathrm{~m}$ and $102 \mathrm{~m}$ were simulated. Visual inspections of the flame extension using Smokeview; a software tool designed to visualise the numerical calculations computed using FDS [22] (Figure 5) and a comparison of the HRR results shown in Figure 10b indicate a domain length of $36 \mathrm{~m}$ was not appropriate whereas $93 \mathrm{~m}$ is sufficient to capture the flame extension for this analysis.

Three fuel configurations were simulated to examine if there was any significant effect on the fire development. Fuel arrangement 1 was used as the baseline and is described in Table 3. Fuel arrangement 2 had the plastic pallets only positioned in layer 3 whereas fuel arrangement 3 had the plastic pallets positioned in layers 2 and 4. From the simulation results shown in Figure 11c, it appears that these fuel package arrangements do have an affect on the HRR. Comparing the simulated fuel arrangement layouts with the Runehamar tunnel fire experiment $\mathrm{T} 1$, in terms of the growth rate and peak heat release rate, fuel arrangement 1 has the closer resemblance to the HRR curve from T1 although arrangement 2 gave very similar results. Therefore fuel arrangement 1 was used as the baseline for the other simulation analysis work.

The influence of ventilation on fire in tunnels was investigated. For illustration purposes, velocities of $1 \mathrm{~m} / \mathrm{s}, 1.5 \mathrm{~m} / \mathrm{s}$ and $3 \mathrm{~m} / \mathrm{s}$ were performed similar to ventilation velocities that might be expected from a tunnel smoke control system and Figure 11d indicates there is an increase in the peak heat release rate as the air velocity in the tunnel increases similar to previous experimental observations $[18,19]$. The total simulated energy release at $3 \mathrm{~m} / \mathrm{s}$ was found to be $257 \mathrm{GJ}$ compared with the theoretical $247 \mathrm{GJ}$ experimental value (Table 1). It is also clear that the total energy released increases with velocity and one reason for the enhanced burning may be due to the provision of additional oxygen to the fire improving the mixing in the flames.

The effect of ignition location (rear and front of the trailer, Figure 12) where ignition occurred at the base of fuel stack adjacent to the upper surface of the platform and midway across the lateral extent of the fuel was also studied to examine fire development using longitudinal ventilation in the tunnel. Examination of the fire simulations number 4 and 10 (Figure 11e) shows the location of the ignition source can affect fire development. The results show that in the presence of tunnel air flow that a fire ignited at the upstream of the trailer spreads faster and yields a slightly higher heat release rate as compared to fire ignited at the downstream end of the trailer. Conversely, if the ignition occurs at the downstream end of the fuel load there will be a delay in the fire development. Similar findings have been observed in the large scale fire tests in Second Benelux Tunnel [23]. 


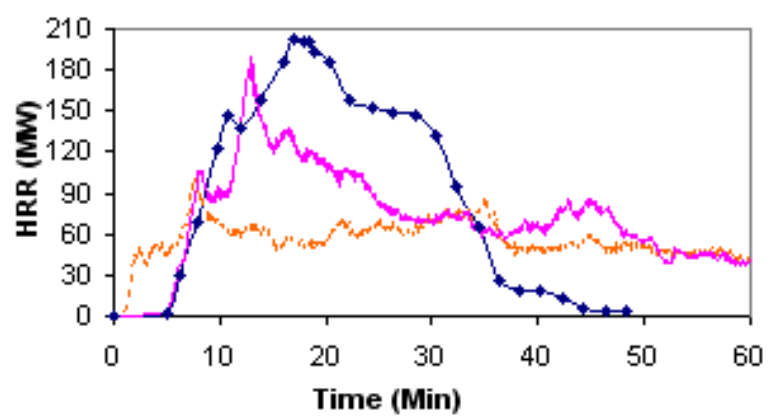

$\longrightarrow$ Fire Test

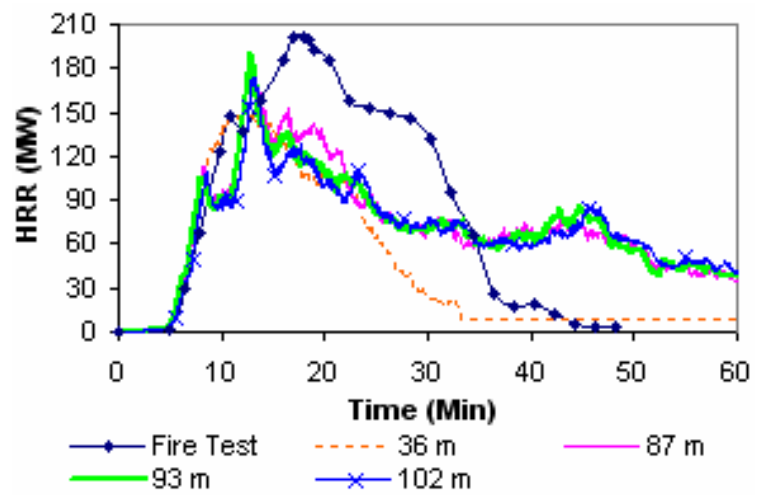

(b) Domain length sensitivity (simulations 2, 3, 4 and 5)

(simulations 1 and 4)

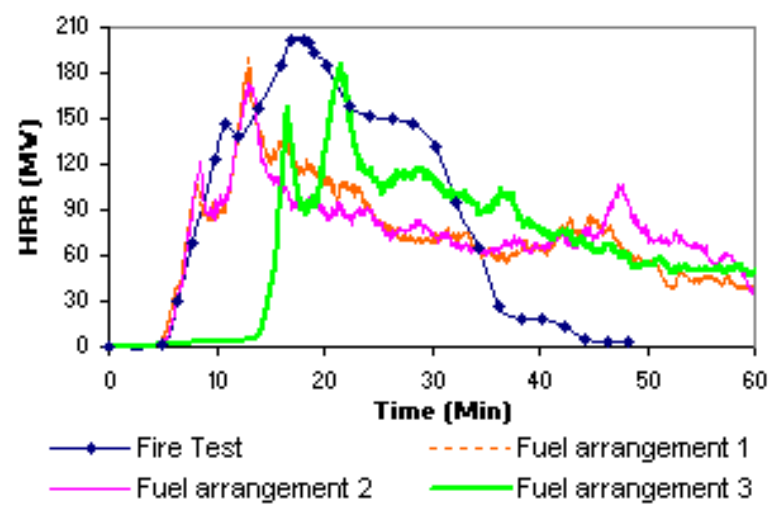

(c): Different fuel arrangement (simulations 4, 6 and 7)

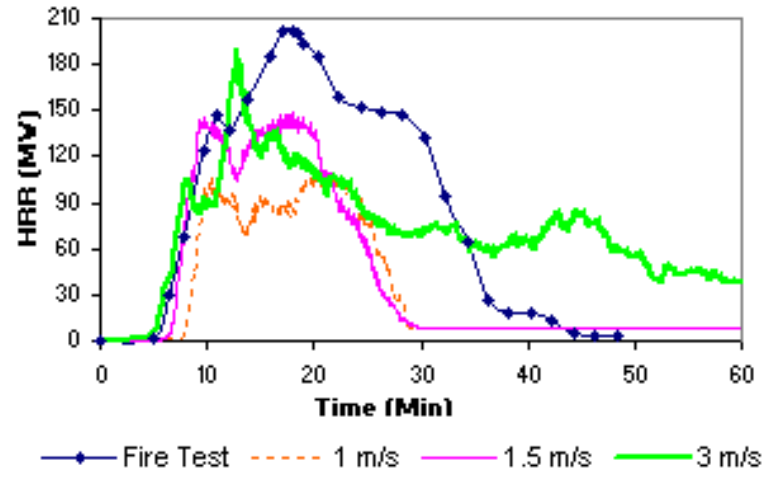

(d) Different tunnel airflow (simulations 4, 8 and 9)

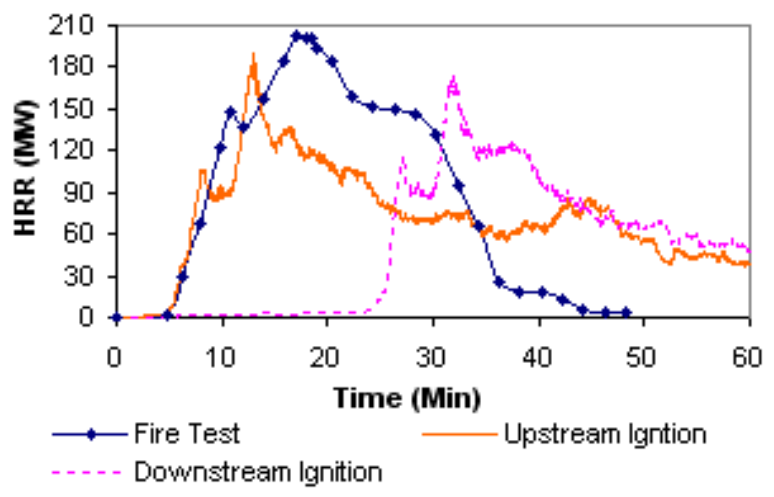

(e) Different ignition location (simulations 4 and 10)

Figure 11: Effect of varying simulation parameters 


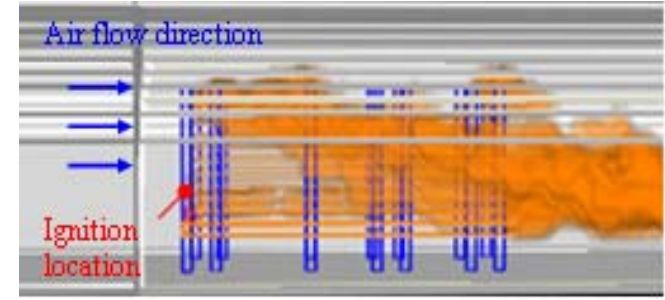

Time 800 sec: Upstream ignition at $3 \mathrm{~m} / \mathrm{s}$

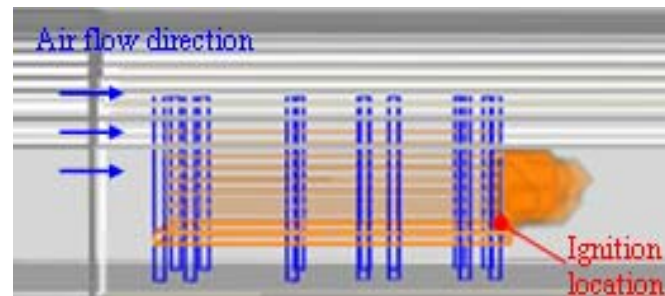

Time 800 sec: Downstream ignition at $3 \mathrm{~m} / \mathrm{s}$

Figure 12: Effect of ignition location on fire behaviour

The chronology of the Runehamar tunnel fire experiment $\mathrm{T} 1$ at 0,5 and 30 minute intervals are shown in Figure 13. Photographs taken from the experiment are compared with the snap shots taken from the Runehamar tunnel simulation number 4 . Although the simulation was able to simulate the growth rate history and peak heat release rate, as expected, phenomena such as collapse of the fuel package during the burning process was not captured. 
Photograph of fire experiment T1

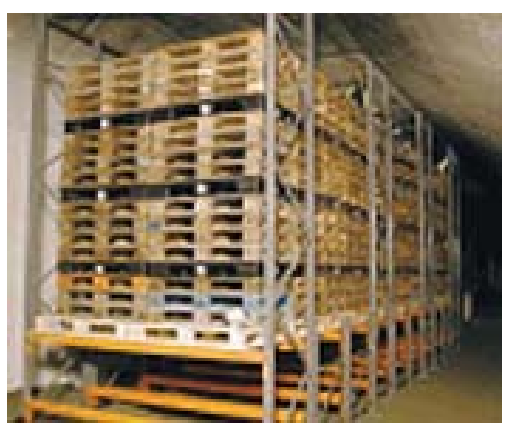

Fuel load at time 0

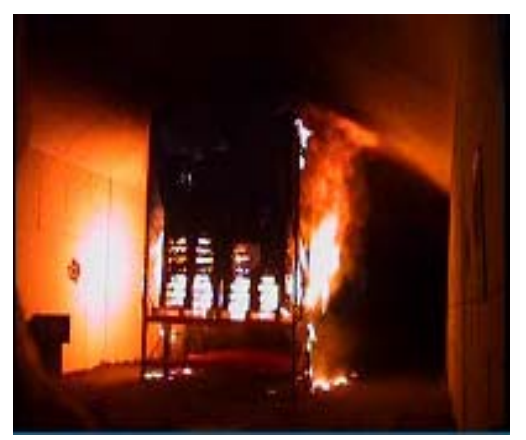

Fire development after 5 minutes

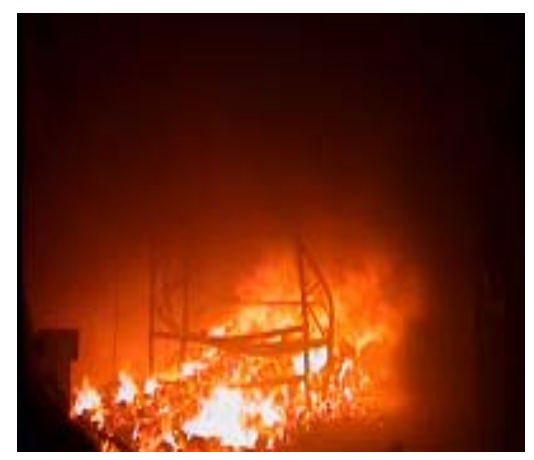

Fire development after 30 minutes

\section{Snap shot from FDS simulation}

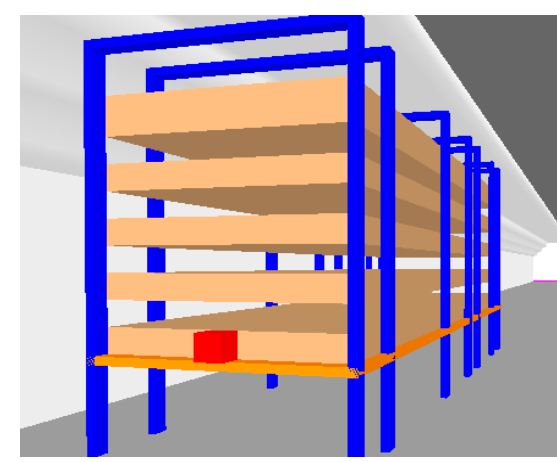

Fuel load at time 0

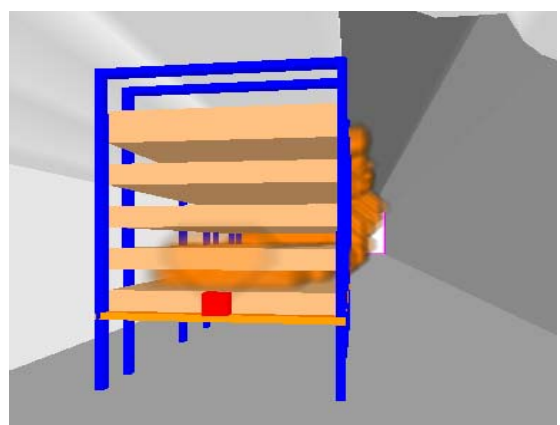

Fire development after 5 minutes

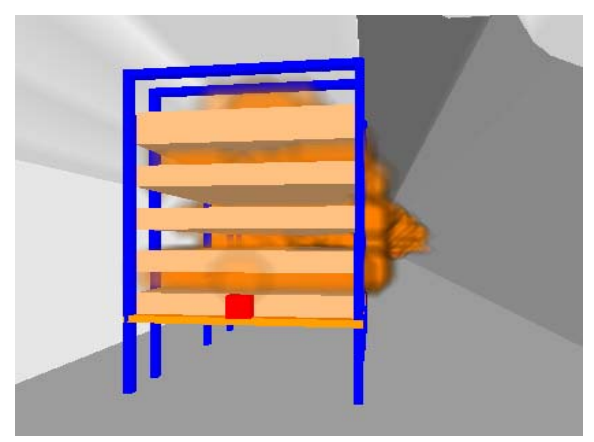

Fire development after 30 minutes

Figure 13: Runehamar tunnel fire events from actual test and FDS simulation (photographs reproduced from ref. 12) 


\section{FINDINGS}

The following findings were obtained when comparing the FDS fire growth curve with the heat release rate in the Runehamar tunnel fire experiment $\mathrm{T} 1$ :

1. Using a grid size of $300 \mathrm{~mm}$ for the simulations was appropriate for the following reasons:

i) The simulations based on a $300 \mathrm{~mm}$ grid produce fairly consistent predictions in terms of the growth phase of the fire development as compared with the actual fire experiment.

ii) From Figure 11a, the $300 \mathrm{~mm}$ grid size provides a closer resemblance in terms of its peak HRR and fire curve as compared with the $150 \mathrm{~mm}$ grid size.

iii) Depending on the computer speed, a typical workstation (Pentium IV, 1 GB RAM) could take more than 39 days to simulate the fire using a grid size of $150 \mathrm{~mm}$ in order to provide results compared with 5 days for the $300 \mathrm{~mm}$ grid.

2. The domain sensitivity shown in Figure 11b illustrates that it is important to define an appropriate domain size for the simulation. A computational domain which is not large enough may not capture all the flame extension produced from the combustion resulting in a lower heat release rate output estimated from the simulation.

3. It is important to ensure the fuel package surface area model in the simulation is equivalent to the fuel package area used in the fire experiments. This can be achieved by introducing a 'surface burning factor' in the simulation as illustrated in this work.

4. To establish the heat release rate in a tunnel, it is important to capture the details of the tunnel geometry and air velocity in the simulation as the effect of reradiation and ventilation conditions in the tunnel are likely to affect the fire development.

5. Depending on the airflow velocity, the fire development in tunnels can vary substantially. Tunnel airflow direction and the ignition location can have a significant effect in delaying or accelerating the propagation of the fire during the initial stages of the fire development. The location of the ignition source at both upstream and downstream of the fire may need to be considered when establishing a design fire for a tunnel. 


\section{CONCLUSIONS}

A calibrated simulation of the Runehamar tunnel fire experiment T1 using FDS 4.0.7 demonstrates that the model is able to capture much of the detail of the fire growth rate and peak heat release rate compared to the experimental result. Although simulation results using this modelling approach look favourable, the current approach has only focused on the modelling of wood and plastic pallets in a trailer. A similar exercise would need to be performed if other commodities (e.g paper cartons, mattresses) with a different fuel arrangement was used for an FDS simulation. Other simulation parameters such as a SBF, the grid size and domain length would need to be re-examined as these modelling assumptions can affect the heat release rate estimate. This work has particularly noted that:

i) The modelling of a complex fire scenario in a CFD model such as FDS is challenging task. Calibrating simulations against experimental data is a useful approach which then allows the effect of varying parameters outside of the original experiments to be investigated.

ii) Although similar growth rate history and peak heat release rate were produced from the simulations, the current model is unable to simulate phenomena such as collapse of the fuel package.

iii) The results from the FDS model show that airflow in the tunnel will have a significant effect on the heat release rate where a higher airflow yields higher heat release rate.

iv) The location of the ignition source will affect the fire growth characteristics of a goods vehicle burning in a tunnel. A fire originating at the upstream end of the fuel package accelerates the fire spread as compared to fire ignition occurring at the downstream end of the fuel package.

\section{NOMENCLATURE}

$\begin{array}{ll}A & \text { Area }\left(\mathrm{m}^{2}\right) \\ D & \text { Diffusion coefficient } \\ H & \text { Height of fuel load }(\mathrm{m}) \\ \Delta H_{O 2} & \text { Energy release per unit mass oxygen consumed }(\mathrm{kJ} / \mathrm{kg}) \\ L & \text { Length of fuel load (m) } \\ \dot{Q} & \text { Total heat release rate }(\mathrm{kW}) \\ m_{O 2}^{\prime \prime \prime} & \text { Production rate of species per unit volume } \\ T & \text { Thickness of the fuel load (m) } \\ t & \text { Time (s) }\end{array}$




$\begin{array}{ll}W & \text { Width of fuel load }(\mathrm{m}) \\ Y & \text { Mass fraction of species } \\ Z & \text { Mixture fraction } \\ \text { C_P } & \text { Specific heat }(\mathrm{kJ} / \mathrm{kg} . \mathrm{K}) \\ \text { HRRPUA } & \text { Heat release rate per unit area }\left(\mathrm{kW} / \mathrm{m}^{2}\right) \\ \text { TMPIGN } & \text { Ignition temperature }\left({ }^{\circ} \mathrm{C}\right) \\ \text { KS } & \text { Thermal conductivity }(\mathrm{W} / \mathrm{m} . \mathrm{K}) \\ \text { SBF } & \text { Surface burning factor } \\ \rho & \text { Density }\left(\mathrm{kg} / \mathrm{m}^{3}\right)\end{array}$

\section{ACKNOWLEDGEMENTS}

The authors would like to thank Dr H Ingason and Dr A Lönnermark of SP Swedish National Testing and Research Institute for providing the information on the Runehamar tunnel fire tests. M.K Cheong also wishes to thank the Land Transport Authority of Singapore for providing a scholarship grant for his research work. The Fire Engineering programme at the University of Canterbury is supported by the New Zealand Fire Service Commission.

\section{REFERENCES}

1. Bendelius A., "Fire Protection for Road Tunnels", In Fire Protection Handbook, National Fire Protection Association (NFPA), Quincy MA, pp.14-127 to 14-144, 2003.

2. PIARC, Fire and smoke control in road tunnel, Permanent International Association of Road Congress, 1999.

3. NFPA 502, Standards for road tunnels, bridges and other limited access highways, 2004 edition, National Fire Protection Association, Quincy, Massachusetts.

4. BD78/99 - Design manual for road and bridges, The Highway Agency, August 1999.

5. Ingason H., Lönnermark A., "Heat release rates from heavy goods vehicle trailer fires in tunnels”, Fire Safety Journal, Vol. 40, pp.646-668, 2005.

6. Rein G., Abecassis Empis C., Carvel R.O., The Dalmarnock fire tests: Experiments and modelling, School of Engineering and Electronics, University of Edinburgh, ISBN 978-0-9557497-0-4, 2007. 
7. Ingason H., Lönnermark A., "Project description and planning of large-scale tests in Runehamar tunnel”, SP Swedish National Testing and Research Institute, August 2003.

8. Lönnermark A., Ingason H., "Gas Temperatures in Heavy Goods Vehicle Fires in Tunnels", Fire Safety Journal, 40, 506-527, 2005.

9. Brekelmans J., Bosch R.V., "Summary of large scale fire tests in the Runehamar tunnel in Norway”, Published by: UPTUN, TNO, PROMAT, September 2003.

10. McGrattan K., "Fire Dynamics Simulator (Version 4) Technical Reference Guide", National Institute of Standards and Technology, September 2005.

11. McGrattan K., Forney G., "Fire Dynamics Simulator (Version 4) User’s Guide”, National Institute of Standards and Technology, September 2005.

12. Drysdale D, “An Introduction to Fire Dynamics” 2nd Edition, John Wiley \& Sons Ltd, 1998.

13. Promat, "Full Scale Fire Tests - Thermal protection boards, Runehamar tunnel, Norway”, Promat Tunnel, http://www.promat-tunnel.com/en/thermal-protectionboards.aspx , accessed 19 February 2007.

14. White M.S., "Pallets Move the World - The need for international pallets standards", ISO Bulletin, Pallet \& Container Research Laboratory, http://www.iso.org/iso/en/commcentre/pdf/Pallets0008.pdf , accessed 5 March 2007.

15. Thureson P., "Eurefic - Cone Calorimater Test Results Project 4 of the Eurefic fire research programme”, SP Swedish National Testing and Research Institute Fire Technology, 1991.

16. Babrauskas V., Grayson S. J., Heat Release in Fires, London; New York: Elsevier Applied Science, 1992.

17. Babrauskas V., Ignition handbook: principles and applications to fire safety engineering, fire investigation, risk management and forensic science, Fire Science Publishers, 2003.

18. Ingason H., Gustavsson S., Dahlberg M., "Heat Release Rate Measurement in Tunnel Fires”, SP Swedish National Testing and Research Institute Fire Technology, SP report 1994.

19. Cavel R.O., Beard A. N., Jowitt P.W., Drysdale D.D., "The influence of Tunnel Geometry and Ventilation on the Heat Release Rate of a Fire”, Fire Technology, v 40, no 1, pp.5-26, 2004 
20. DiNenno P. (ed.). The SFPE Handbook of Fire Protection Engineering ( ${ }^{\text {rd }}$ ed.), Appendix B, NFPA, Quincy, MA, 2002.

21. Beard, A.N., “Tunnel Fire Safety: Prevention, Protection and Ventilation”, China Tunnel Summit-2008, 20-21 March 2008, Shanghai.

22. Forney G.P., McGrattan K., "User's Guide for Smokeview Version 4”, National Institute of Standards and Technology, August 2004.

23. Lemaire T., Kenyon Y., "Large Scale Fire Tests in the Second Benelux Tunnel”, Fire Technology, 42, pp.329-350, 2006. 